\title{
Skills teaching in COVID lockdown in the UK: lessons learnt
}

Wprowadzenie. Dystansowanie społeczne to jeden ze środków bezpieczeństwa zalecanych w trakcie pandemii spowodowanej COVID 19. Pomaga to ograniczać transmisję wirusa poprzez zwiększanie fizycznej odległości oraz redukowanie częstotliwości spotkań w miejscach w których przebywa duża liczba osób, takich jak uniwersytety czy miejsca pracy. W odpowiedzi na wspomniane restrykcje, Szkoła Pielęgniarstwa i Położnictwa Uniwersytetu Birmingham niezwłocznie przekształciła większość zajęć studentów w tryb online. Jednak w przypadku studentów kierunków medycznych taka forma nie zawsze wydaje się możliwa, zwłaszcza w odniesieniu do umiejętności klinicznych, które nie mogą być nauczane w trybie zdalnym. Uniwersytet Birmingham w ostatnim czasie aktywnie poszukiwał rozwiązań dotyczących potrzeb nauczania tego typu umiejętności. W kwietniu otwarto kampus działający jako Centrum Szkolenia Umiejętności aby pomóc setkom studentów podnieść kwalifikacje poprzez podjęcie się przez nich rozszerzonej praktyki zawodowej w formie wsparcia dla pracowników służby zdrowia walczących na pierwszej linii frontu z COVID 19. Kiedy Uniwersyteckie Centrum Szkolenia Umiejętności zostało otwarte, faza planowania skupiała się na zapewnieniu kadrze i studentom bezpieczeństwa.. Podsumowanie. Wdrożone plany oznaczały, że nauczanie umiejętności klinicznych musiało być zorganizowane inaczej niż przed izolacją, w sposób bezpieczny i możliwy do utrzymania dla przyszłych potrzeb.

Słowa kluczowe: COVID 19, pandemia, umiejętności kliniczne, izolacja, zdalne nauczanie

Introduction. Social distancing is one of the community mitigation measures that has been recommended during the COVID 19 pandemic. Social distancing can reduce virus transmission by increasing physical distance or reducing frequency of meeting in socially dense community settings, such as Universities or workplaces. In response to this, Birmingham City University School of Nursing and Midwifery rapidly developed and transferred much of their student learning online. However, for healthcare students this is not always practicable and is particularly notable in respect to developing clinical skills which cannot be learnt online nor should be attempted for the first time in practice. Birmingham City University has recently actively sought to address such training needs. In April, it opened its campus as a Skills Training Hub to help upskill hundreds of students taking on extended work placement in a bid to bolster frontline NHS workforce numbers to aid in the fight against COVID 19. When opening Birmingham City University Skills Hub, the primary focus of the planning phase was towards promoting staff and student safety.

Conclusions. The plans that were put in to place meant that clinical skills teaching had to be organised differently from how it was before lockdown and in a way that was safe and sustainable for future needs.

Key words:

COVID 19, pandemic, clinical skills, lockdown, learning online 


\section{INTRODUCTION}

Social distancing involves reducing day to day contact with other people as much as possible in order to reduce the spread of coronavirus (COVID 19) [1]. In response to this, in the UK, Birmingham City University School of Nursing and Midwifery rapidly developed and transferred much of their student learning online and are encouraging their students to engage with a multitude of virtual learning activities to best enable their learning progress. However, for healthcare students this is not always practicable. This is particularly notable in respect to developing clinical skills, the tactile practice of which, cannot be learnt online nor should be attempted for the first time in practice.

Therefore, the question arises, how to enable such learning safely in line with government guidance towards ensuring learners enter the practice learning environment with the relevant practiced skills needed. Birmingham City University actively sought to address such training needs. In April, it opened its Seacole building as a Skills Training Hub to help upskill hundreds of students taking on extended work placement in a bid to bolster frontline clinical workforce numbers to aid in the fight against COVID 19. When opening Birmingham City University Skills Hub, the primary focus of the planning phase was towards promoting staff and student safety.

\section{Assessment of Risks}

Everyone who entered the building needed to assess and manage the risks of COVID 19. As a University in the UK, there is a legal responsibility to protect students and others from risk to their health and safety. This meant there was a need to think about the risks faced and do everything reasonably practicable to minimise them, recognising you cannot completely eliminate the risk of COVID 19 transmission. It was of vital importance to make sure that an in-depth risk assessment was completed, and it addressed the risks of COVID 19, utilising this guidance to inform any decisions and control measures. The risk assessment was not about creating huge amounts of paperwork, but rather about identifying sensible measures to control the risks in the building. The risk assessment helped coordinators to decide whether everything was done that needed to be.

\section{Staff Consultation}

Universities in the UK have a duty to consult their staff on health and safety [2]. This was done by meeting, listening, and talking to key staff about the work required and how we were to manage risks from COVID 19. The people who do the work are often the best people to understand the risks in the workplace and will have a view on how to work safely. Involving them in making the decisions showed that the university took the health and safety of students and staff seriously. This was most effective, allowing full involvement of the workers created a culture based on collaboration, trust and joint problem solving. An initial and wide consultation phase was entered into which included, but was not limited to, campus service's and space management staff, security staff, administration staff, catering, and cleaning services.

Strict two metre distancing procedures were implemented at every opportunity, and all Skills Hub attendees were reminded of this with visible floor and wall signage. Student numbers were closely managed, and a limited number invited to attend on each day. Entrance into the building was strictly administered through a signing in and out procedure and floor mapping was introduced to ensure a one directional flow of students and staff within the building, reducing the risk of breaking the two metre distancing within corridors. Staff and students were all issued with Personal Protective Equipment including face masks and eye protection. Regular hand washing for twenty seconds with soap and water was encouraged and hand sanitising stations were operated as students and staff entered and exited teaching spaces. Each room had individual learning spaces two metres apart and equipment used was sanitised carefully between users. All rooms and equipment were deep cleaned at the end of each day.

\section{Opening the skills Hub}

The BCU skills Hub first opened its doors to third year nursing students nearing the end of their training in order to focus on upskilling students in line with Nursing and Midwifery Council (2018) Education Standards Annex B Nursing Procedures [3], for which the planned incorporation into their training had been thwarted by the initial COVID 19 lockdown. The University worked closely with practice partners in local hospitals to ensure the skills taught were in line with partner requirements. The aim of the skills hub was to not only to enable training in the key techniques and skills needed to aid in the frontline battle against coronavirus, but also to offer students advice and targeted preparation, mindful of their mental wellbeing and resilience as the entered into the current challenges being faced within the clinical environment. Dedicated staff from across Birmingham City University Health, Education and Life Sciences Faculty, aided with the content creation which focused on front loading the students learning with online pre attendance theory activities and then subsequently with the delivery of the skills teaching required, demonstrating true interdisciplinary working.

The attention paid to preparing for the BCU Skills Hub opening has ensured that if and when required, the skills hub can open to learners with as little as seventy two hours' notice; future proofing any required skills training delivery needs in as safe an environment as possible, as the virus continued to unfold.

\section{Summary and recommendations}

In summary, some general principles that were noted for consideration will be relevant for the majority of Universities and clinical skills training centres planning similar training activities during this time. These were:

- Make regular targeted announcements to remind staff and students to follow social distancing advice and wash their hands regularly 
- Encourage the use of digital and remote transfers of material where possible rather than paper format, such as using e-forms and emails, signing in sheets

- Provide handwashing facilities with soap and water and hand sanitising stations and encourage their use

- Where it is possible to remain two metres apart, use of floor markings to mark the distance, particularly in the most crowded areas e.g. where queues are likely to form

- Where it is not possible to remain two metres apart such as when closer contact is required teaching a clinical skill, staff and students should work side by side, or facing away from each other, rather than face to face and relevant PPE should be worn by both parties

- Where face-to-face contact is essential, this should be kept to fifteen minutes or less

- As much as possible, keep teams of workers together and keep teams and teaching groups sizes as small as possible

Additionally:

- Use signage to direct movement around buildings to maintain two metre distancing

- Regulate entry so that the premises do not become overcrowded

- Check with all attendees that they are symptom free and use additional signage to ask individuals not to enter the premises if they have any symptoms including cough or fever.

The plans that were put in to place meant that clinical skills teaching had to be organised differently from how it was before lockdown and in a way that was safe and sustainable for future needs.

\section{ORCID}

Stephen Wanless (iD https://orcid.org/0000-0001-7906-5111

Emma Winterman (iD https://orcid.org/0000-0002-4752-718X

Jim Chapman (iD https://orcid.org/0000-0002-4551-0405

\section{REFERENCES/PIŚMIENNICTWO}

1. Dept of Health and Social Care. Coronavirus action plan: a guide to what you can expect across the UK. Crown Copyright; 2020. [online] https://www.gov.uk/ government/publications/coronavirus-action-plan/coronavirus-action-plan-aguide-to-what-you-can-expect-across-the-uk

2. Health and Safety Executive. Talking with your workers about preventing coronavirus. Crown Copyright; 2020. [online] http://www.hull.gov.uk/sites/hull/ files/media/HSE_-_Talking_wit.pdf

3. Nursing and Midwifery Council. Future Nurse: Standards of proficiency for registered nurses. NMC; 2018.

Manuscript received: 18.05 .2020

Manuscript accepted: 01.06.2020 